AGRICULTURE AND BIOLOGY JOURNAL OF NORTH AMERICA

ISSN Print: 2151-7517, ISSN Online: 2151-7525, doi:10.5251/abjna.2011.2.1.143.149

(C) 2011, ScienceHuß, http://www.scihub.org/ABJNA

\title{
A survey of the economically valued forest plant species at the proposed site for airport in Asaba, Delta State, Nigeria
}

\author{
Agbogidi, O. M. \\ Department of Forestry and Wildlife, Faculty of Agriculture, Delta State University, Asaba \\ Campus, Nigeria. \\ omagbogidi@yahoo.com, +2347038679939 or +2348056306219
}

\begin{abstract}
This study assessed the economically valued forest plant species at the proposed site for airport in Asaba, Delta State Nigeria in 2006. $2520 \mathrm{~m}$ x 20m quadrants were laid randomly along five $1 \mathrm{~km}$ line transect and accordingly assessed. Thirty tree species producing various economically valued products were assessed and trees $30 \mathrm{cmlong}$ and above were counted as present. Tree species 10 out of the 33 were observed to be rare while 23 were abundant. Fifteen species of shrubs were assessed out of which, 8 were identified as abundant and rare (3). Products collected from theses plants have varying use categories as leafy vegetables, edible and medicinal fruits, leaves, seeds barks, fodder, poles, timber, stakes and chew sticks. The study established that over exploitation, exploration and conversion of forest ecosystems result in the area has brought about decimation of biodiversity as well as extinction of many valuable plant and animal species. It is strongly recommended that domestication of indigenous tree and shrub species should be encouraged and supported.. Conservation efforts through the establishment of nature reserves, botanical gardens, sacred grooves, sanctuaries, rare breed centers, game banks and on-site gene banks should be supported to enhance sustainability.
\end{abstract}

Keywords: Forest trees, shrubs, proposed site, Airport, Asaba, Delta State.

\section{INTRODUCTION}

The environment according to Agbogidi and Ofuoku (2007) is the closest neighbour of man. Man depends directly and indirectly on the environment for almost everything relating to growth and survival on planet earth. Among the major biotic components of the environment are forests and other vegetation and the wise management of the environment depends on a better understanding of its components. Given the dynamic nature of the global ecosystem, environment changes, driven by man-made and natural cause is inevitable. Economic activities and the rate of population growth have increased to a point where the effect of humanity on the environment can no longer be ignored (Aimufia, 2002).

The importance of forest to mankind cannot be overemphasized Agbogidi and Eshegbeyi (2008) noted that forests and forest products play vital roles in human life from the cradle to the grave. Aimufia (2002) emphasized that the cot on which the baby lies at birth, the buildings and furniture he uses, at the various levels of his education, his endeavours in industry and agriculture, the accommodation and furniture he acquires as a worker/ entrepreneur, his diet and health sustaining systems, the armchair, he relaxes on his old age, and the coffin or casket in which he returns to Mother earth are forest dependent. Keay et al. (1989) and Abu and Adebisi (2002) stated that the traditional uses of forests are basically for subsistence, income, environmental and social/ culture. Burkill (1985) and Agbogidi and Eshegbeyi (2008) maintained that forests are often called the lungs of the earth for their role in the contribution to carbon sequestration and other global ecological services yet everywhere we look the lungs are gasping. Udo (2001) noted that forest benefits include tangible benefits-wood products and non-wood products and environmental benefits (Table 1). Etukudo (2000) emphasized that forests are man's divine treasure.

Aliyu (2006) stated that reasonable numbers of medicinal species are threatened by habitat loss following heightened deforestation (Agbogidi, 2002; Agbogidi and Ofuoku, 2006). Although there is a great incompatibility between urbanizations/ industrializations and agriculture and conservation developmental activities should be environmentally friendly to allow for a sustained productivity (Agbogidi and Okonta, 2009). Anthropogenic activities including farming, hunting, tree felling, bush burning, mining operation, petroleum exploitation, civil engineering 
construction and water exploration have been shown to impact the forest negatively (Adeyemi and Jegede, 2002). Adelusi et al. (2002) noted that urban forest reserves and enclaves have suffered more and undue depletion and degradation with loss of biodiversity and renewable resources as a result of urbanization and encroachment on areas originally perceived as forest reserves and estate. In the same vein, Okonkwo et al. (2002) reported that serious anthropogenic activities of man constitute great environmental hazards. Impact of certain projects on the vegetation of ecosystems in the tropics including Nigeria is widespread. For example, establishment of modern markets, television stations, amusement parks, housing estate, company sites, stadium in Nigeria and other parts of the tropics has led to the removal and destruction of various economic vegetation, the use of some are yet to be discovered.

The link between the environment and human survival calls for environmental impact assessment of a deemed large-scale economic project that will impact the generality of the populace and Asaba in particular. This study has been undertaken to assess the economically valued forest trees and shrubs likely to be lost on the proposed site of airport in Asaba, Delta State with a view to reaching them before their utter disappearance on the conversion of the area to an Airport.

Table 1. Benefits of Forests

\section{Benefits of Forests}

1. Wood and non-wood products

a.Wood products:

Saw logs, veneer logs, pulpwood, poles, matchwood, chew sticks, yam stakes etc.

b. Non-wood products

Leaves, forage, fruits and seeds, medicinal herbs, tannins (dyes), latex, resins, gums, canes/ rattans, laterite, honey, mushrooms, wildlife.

2. Environmental benefits

a.Environmental/ protection

Soil protection against erosion, purification of air, protection of houses against windstorm, protection of water catchments, provision/ protection of wildlife habitats, windbreak against desert encroachment, cooling of the environment, protection of plants, animals and man against excessive sunrays, regulation of drought and flood, amelioration of climate, habour unique genetic resources.

b. Nutrient and hydrological cycles

Helps in nutrient cycling to improve soil fertility, contribute to hydrological cycle, control of semimetals of down stream bodies, control of ground water recharge.

c.Aesthetics and education

Beautification of avenues and improvement of landscape, research ground on biodiversity, provision of tourism and recreational facilities.

Source: Etukudo, 2000; Udo, 2001; Agbogidi and Eshegbeyi, 2008.

\section{MATERIALS AND METHODS}

The experiment was conducted at latitude $6^{0} 14^{1} \mathrm{~N}$ and longitude $6^{0} 49^{1} \mathrm{E}$ at the proposed site for airport in Asaba, Delta State, Nigeria (Asaba Meteorological Office, 2006). Asaba lies in the humid low land tropical vegetation. The study was conducted using line transects. Five $1 \mathrm{~km}$ line transects were laid at 150 meters interval. The transects ran through forest and the surrounding farm fallow $25.20 \mathrm{~m} \times 2 \mathrm{~m}$ quadrants were points along each of the transects following the procedure of Olajide et al. (2006). Assessment of forest plant species producing economically valuable products subsequently followed. A total area of $10,000 \mathrm{~m}^{2}$ was assessed along each transect which summed up to a gross total area of about 5 hectares. Direct counting of present plants of $30 \mathrm{~cm}$ and above assessed plant species was done. A plant species was classified as abundant or rare based on its frequency count in all the assessed quadrants. A plant species found in 40 percent and above of all the assessed quadrants was considered abundant while a species present in less than 40 percent of all the assessed quadrants was regarded rare following the procedure of Olajide et al. (2006).

\section{RESULTS AND DISCUSSION}

Thirty-three tree species producing various economically valued products were assessed (Table 2). Ten of the 30 trees species were observed to be 
rare while 23 species were abundant (Table 2). Fifteen species of the shrub species were evaluated and twelve (12) were identified as abundant and three (3) rare (Table 2). The economic products that are harvested or collected from these plant species include nuts, fruits, seeds, leaf vegetable, bark, leaves, fodder, chew sticks, poles, stakes, timber, juices, resins and dyes and have varying use categories as medicine, food, local construction, craft as well as other uses including socio-cultural and environmental values (Jimoh and Haruna; 2007; Agbogidi and Eshegbeyi, 2008; Idumah et al., 2008; Adedodun et al., 2010).

Over exploitation, exploration and utter conversion of forest ecosystems or other land use normally result in the decimation of biological diversity as well as in extinction of many valuable plant and animal species (Agbogidi, 2002; Iroko et al., 2008). The studied area could have been under intensed exploitation for commercially valued products attributed mainly to man-influenced activities (anthropogenic forces). The disappearance of many economically valued tree and shrub species across Nigeria is a well-known phenomenon (Agbogidi and Ofuoku, 2006; Adekunde and Akinlemibola, 2008; Olajide et al; 2008; Sale et al., 2008; Oni et al., 2010). Deforestation for various reasons are equally evident (Adeyoju, 2001; Adeyemo and Jegede, 2002; Agbogidi, 2002; Aju, 2002; Foskett and Foskett, 2004; Omotoyinbo and Kayode, 2008: Oguntade and Awolala, 2010). If forests are indiscriminately depleted, the various roles associated with them would be lost. For examples, there will be prevalence of food insecurity, environmental problems would be on the increased as there will heightened climate change resulting in reduced immunity and outbreak of various diseases leading to eventual death of organisms including the species called man as emphasized by Nwoboshi (2001) that when the last tree on planet earth dies, the man dies also.

There is an ultimate need for conservation of biodiversity (Foskett and Foskett, 2004) the goal for sustainable development (Agbogidi and Okonta,
2009). The 10 rare species of the forest observed in the studied area could be as result of habitat loss the forest ecosystem in the studied area. As observed in the studied area, there is already over exploitation of economically valued trees and shrub species in parts of the study area-Asaba which calls for the preservation of the ecosystem. On conversation to airport, most of the remaining species will be definitely lost. Domestication of indigenous tree and shrub species is advocated both for poverty alleviation in rural communities like Asaba and for a balance to be maintained in the ecosystem (Oregbeme, 2005; Jimoh and Haruna, 2007 and Kuponiyi, 2007). Popoola and Oluwalana (1998), Popoola (2002), Anamayi et al. (2005) and Olufemi and Akinlosutu (2006) shared similar view. Planting of edible and medicinal forest plant species in Asaba should be strongly encouraged and supported with the inhabitants of the area with strong incentives from Government such as supplying of seedlings, seeds and employment of the people. Nature reserves, groves and sanctuaries should be established in the area to enhance conservation strategies and to ensure sustainability.

\section{CONCLUSION}

This study assessed the proposed site of the airport in Asaba, Delta State for forest tree and shrub species which produce economically valued products. Out of the 33 tree species assessed, 23 were abundant while 10 rare. While 12 species were abundant and 3 rare and the 15 shrub species assessed. Over exploitation and exploration of the species were reported evident. The study established that at the commencement of the airport following the utter conversion, very many species of trees and shrubs with economically valued products will go into extinction. There is need to encouraged and support the multiplication and domestication of indigenous species. Conservation efforts through the establishment of nature reserves, botanical gardens, sacred grooves, sanctuaries, rare breed centers, game banks and on-site gene banks should be supported to enhance sustainability. 
Table 2. Economically valued tree and shrub species at the proposed airport site in Asaba, Delta State, Nigeria

\begin{tabular}{|c|c|c|c|c|c|c|c|}
\hline s/n & Scientific name & $\begin{array}{l}\text { Common /local } \\
\text { name }\end{array}$ & Habit & $\begin{array}{l}\text { Total abundance } \\
(\%)\end{array}$ & Products & Local uses & Ecological status \\
\hline 1 & Juglans nigra & African walnut & $\mathrm{T}$ & 24 & Seeds & $\mathrm{F}$ & $\mathrm{R}$ \\
\hline 2 & Garcinia cola & Bitter kola & $\mathrm{T}$ & 46 & Seeds & $\mathrm{F}, \mathrm{M}$ & A \\
\hline 3 & Irvingia gabonensis & Dikanut (ogbono) & $\mathrm{T}$ & 20 & Seeds, fruits & $\mathrm{F}$ & $\mathrm{R}$ \\
\hline 4 & Alstonia boonei & $\begin{array}{l}\text { Awan/etinrim } \\
\text { (Yoruba) }\end{array}$ & $\mathrm{T}$ & 43 & Leaves, bark & $\mathrm{M}$ & A \\
\hline 5 & Azadirachta indica & Neem & $\mathrm{T}$ & 42 & $\begin{array}{l}\text { Bark, roots, } \\
\text { leaves }\end{array}$ & $\mathrm{M}$ & $A$ \\
\hline 6 & Anthonotha macrophylla & Aban (Itsekiri) & $\mathrm{T}$ & 17 & Leaves & $\mathrm{F}$ & $\mathrm{R}$ \\
\hline 7 & Pentaclethra macrophylla & Oil bean & $\mathrm{T}$ & 43 & Fruits & $\mathrm{F}, \mathrm{M}$ & $\mathrm{A}$ \\
\hline 8 & Monodora myristica & African nutmeg & $\mathrm{T}$ & 22 & $\begin{array}{l}\text { Seeds, leaves, } \\
\text { bark }\end{array}$ & $\mathrm{F}, \mathrm{M}$ & $\mathrm{R}$ \\
\hline 9 & Gambeya albida & $\begin{array}{l}\text { African star apple } \\
\text { (udara lgbo) }\end{array}$ & $\mathrm{T}$ & 53 & Fruit & $\mathrm{F}, \mathrm{M}$ & $A$ \\
\hline 10 & Treculia africana & African bread fruit & $\mathrm{T}$ & 51 & Fruits & $\mathrm{F}, \mathrm{M}$ & A \\
\hline 11 & Tetrapleura tetraptera & Aridan plant & $\mathrm{T}$ & 46 & Spice & $\mathrm{F}, \mathrm{M}$ & A \\
\hline 12 & Xylopia aethiopica & Guinea pepper & $\mathrm{T}$ & 50 & Spice & $\mathrm{F}, \mathrm{C}$ & $A$ \\
\hline 13 & Elaeis guinensis & Oil palm & $\mathrm{T}$ & 51 & Fruit, stem & $\mathrm{F}, \mathrm{W}$ & $A$ \\
\hline 14 & Ricinus cummunis & Caster oil & $\mathrm{S}$ & 24 & Fruit, leaves & $\mathrm{F}, \mathrm{M}$ & $\mathrm{R}$ \\
\hline 15 & Vitallaria parodoxa & Shear butter & $\mathrm{T}$ & 18 & $\begin{array}{l}\text { Roots, nuts, } \\
\text { leaves }\end{array}$ & $\mathrm{F}, \mathrm{M}$ & $\mathrm{R}$ \\
\hline 16 & Prosopis africana & Locust bean & $\mathrm{T}$ & 62 & Fruits, roots & $\mathrm{F}, \mathrm{Fd}, \mathrm{M}$ & A \\
\hline 17 & Bombax costatum & Bombax & $\mathrm{T}$ & 26 & Leaves & $\mathrm{F}, \mathrm{M}$ & $\mathrm{R}$ \\
\hline 18 & Raffia hookerri & Raphia palm & $\mathrm{T}$ & 62 & Wine & $\mathrm{W}$ & A \\
\hline 19 & Cola nitida & Kola nuts & $\mathrm{T}$ & 60 & Fruit & $\mathrm{M}, \mathrm{S}$ & A \\
\hline 20 & Oxytenanthera albyssinica & Bamboo & $\mathrm{S}$ & 48 & Stem & C, Co & A \\
\hline 21 & Cocos nucifera & Coconut & $\mathrm{T}$ & 41 & Fruit, leaves & $\mathrm{F}, \mathrm{C}$ & A \\
\hline 22 & Milica excels & Iroko & $\mathrm{T}$ & 27 & Stem & $\mathrm{T}$ & $\mathrm{R}$ \\
\hline 23 & Ficus capensis & Opoto & $\mathrm{T}$ & 47 & Stem & $\mathrm{T}$ & A \\
\hline 24 & Baillenolla toxisperma & African pear wood & $\mathrm{T}$ & 49 & Stem & $\mathrm{CO}, \mathrm{Ww}, \mathrm{M}$ & A \\
\hline 25 & Gliricidia sepium & Gliricidia & $\mathrm{T}$ & 48 & Leaves, stems & Fo, Co, Ww & A \\
\hline 26 & Leucaena leucocephala & Leucaena & $\mathrm{S}$ & 50 & Leaves, stems & $\mathrm{M}, \mathrm{Sc}$ & A \\
\hline 27 & Terminalia superb & White afara/limba & $\mathrm{T}$ & 13 & $\begin{array}{l}\text { Leaves, stems, } \\
\text { roots }\end{array}$ & $\mathrm{Tm}$ & $\mathrm{R}$ \\
\hline
\end{tabular}


Agric. Biol. J. N. Am., 2011, 2(1): 143-149

\begin{tabular}{|c|c|c|c|c|c|c|c|}
\hline 28 & Masonia altisoma & Masonia & $\mathrm{T}$ & 42 & Stem & $\mathrm{Tm}$ & A \\
\hline 29 & Laccosperma species & & $\mathrm{S}$ & 16 & Rattan & $\mathrm{Fu}, \mathrm{B}$ & $\mathrm{R}$ \\
\hline 30 & Eremospatha species & & $\mathrm{S}$ & 44 & Rattan & $\mathrm{Fu}, \mathrm{B}$ & A \\
\hline 31 & Oncocalamus species & & $\mathrm{S}$ & 47 & Rattan & $\mathrm{Fu}, \mathrm{B}$ & A \\
\hline 32 & Momordica charantia & Ejinrin (Yoruba) & $\mathrm{S}$ & 48 & Leaves, roots & $\mathrm{M}$ & A \\
\hline 33 & Tetracarpidum conapharum & Ukpa (Igbo) & $\mathrm{S}$ & 42 & Nuts, leaves & $\mathrm{F}, \mathrm{M}$ & A \\
\hline 34 & Annona muricata & Sour sop & $\mathrm{T}$ & 50 & Fruit & $\mathrm{F}, \mathrm{M}$ & A \\
\hline 35 & Moringa oliefera & $\begin{array}{l}\text { Miracle tree /drum } \\
\text { stick }\end{array}$ & $\mathrm{T}$ & 53 & Leaves & Fo, M & $A$ \\
\hline 36 & Dennittia tripetala & Pepper fruit & $\mathrm{T}$ & 48 & Fruits, roots & $\mathrm{F}, \mathrm{M}$ & $A$ \\
\hline 37 & Vernonia amygdallina & Bitter leaf & $\mathrm{S}$ & 62 & Leaves & $\mathrm{F}, \mathrm{St}$ & A \\
\hline 38 & Dialium guineenese & $\begin{array}{l}\text { Velvet /black } \\
\text { tamarind }\end{array}$ & $\mathrm{S}$ & 56 & Stem, fruits & $\mathrm{M}, \mathrm{W}$ & $A$ \\
\hline 39 & Thaumatococus daniella & $\begin{array}{l}\text { Tamarin /ewe iron } \\
\text { (yoruba) }\end{array}$ & $\mathrm{T}$ & 49 & leaves & $\mathrm{M}$ & $A$ \\
\hline 40 & Afzellia africana & Afzelia /apa & $\mathrm{S}$ & 60 & Roots & $\mathrm{F}, \mathrm{O}$ & A \\
\hline 41 & Landolphia dulcis & Ischeku (Igbo) & $\mathrm{S}$ & 64 & Fruits & $\mathrm{F}, \mathrm{M}$ & $A$ \\
\hline 42 & Myrianthus arboreus & Ujuju (Igbo) & $\mathrm{S}$ & 35 & leaves & Fo & $\mathrm{R}$ \\
\hline 43 & Alchornia cordifolia & Christmas bush & $\mathrm{T}$ & 27 & Leaves & Sk, Mw & $\mathrm{R}$ \\
\hline 44 & Laphira lanceolata & Chewsticks & $\mathrm{T}$ & 64 & Stems & $\mathrm{Mw}, \mathrm{M}$ & A \\
\hline 45 & Laphira alata & Chewsticks & $\mathrm{S}$ & 61 & $\begin{array}{l}\text { Leaves, tender } \\
\text { stem }\end{array}$ & $\mathrm{F}, \mathrm{M}$ & $A$ \\
\hline 46 & Ocimium gratissimum & $\begin{array}{l}\text { Scented leaves } \\
\text { /curry/ okopia } \\
\text { (Igbo) }\end{array}$ & $\mathrm{S}$ & 34 & $\begin{array}{l}\text { Exudates, } \\
\text { leaves, roots }\end{array}$ & $\mathrm{M}$ & $\mathrm{R}$ \\
\hline 47 & Jatropha curcas & Physic nut & $\mathrm{S}$ & 56 & Leaves, roots & $\mathrm{M}, \mathrm{Fo}$ & $\mathrm{A}$ \\
\hline 48 & Carpolobia lutea & & $\mathrm{S}$ & 49 & Leaves, roots & $\mathrm{M}, \mathrm{Fo}$ & $A$ \\
\hline
\end{tabular}

Source: Field survey, 2006

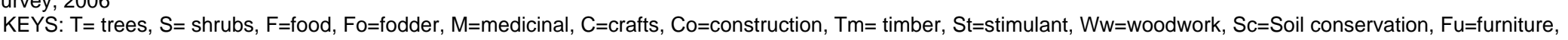
$\mathrm{B}=$ basketry, $\mathrm{W}=$ wine, $\mathrm{Mw}=$ Mouth wash, $\mathrm{Sk}=$ stake, $\mathrm{Wf}=$ wrapping food and $\mathrm{R}=\mathrm{rare}, \mathrm{A}=$ =abundance. 


\section{REFERENCES}

Abu, J. E. and Adebisi, L. A. (2002). A review of traditional forest uses. In: Popoola, (ed.). Proceedings of a National Workshop organized by FANCONSULT and Edo State Chapter of FAN held in Benin-city, Edo State between $5^{\text {th }}$ and $6^{\text {th }}$ of September, 2002. Pp 4250.

Adedodun, M.O., Oladoye, A.O., Olawumi, T.A. and Laminou, K.I. (2010). Economic contribution of Moringa oieifera.(Lam.) plantation to rural livelihoods in Maradi.local government area of Niger Repupublic. Obeche Journal.28 (2): 142-146.

Adekunle, V. A. J. and Akinlemibola, O. (2008). Effect of deforestation on climate change and global warming in Nigeria. In: Popoola, L. (ed.). Proceedings of the $32^{\text {nd }}$ Annual Conference of Forestry Association of Nigeria (FAN) held in Umuahia, Aba State, Nigeria between $20^{\text {th }}$ and $24^{\text {th }}$ October, 2008. Pp 170-182.

Adelusi, H.M., Agboola, O.D. and Oni, P.I. (2002) Urbanisation: implication for forest resources depletion and environmental management in Nigeria. In: Abu, J.E., Oni, P.L. and Popoola, L. (eds.). Proceedings of FAN held in Akure, Ondo State, Nigeria between $4^{\text {th }}$ and $8^{\text {th }}$ of November 2002. Pp 69-79.

Adeyemo, A.I. and Jegede, G. (2002). Effects of anthropogenic actives on Nigerian environment. In: Abu, J.E., Oni, P.L. and Popoola, L. (eds.). Proceedings of FAN held in Akure, Ondo State, Nigeria between $4^{\text {th }}$ and $8^{\text {th }}$ of November 2002. Pp 8993.

Adeyoju, K. (2001). Forestry for national development: a critique of the Nigerian situation. In: Popoola, (ed.). Proceedings of a National Workshop organized by FANCONSULT and Edo State Chapter of FAN held in Benin-city, Edo State between $5^{\text {th }}$ and $6^{\text {th }}$ of September, 2002.Pp 55-84.

Agbogidi, O. M. (2002). Deforestation and the Nigeria's rural environment. In: Ibitoye, O. A. (ed.). Rural environment and sustainable development. Petoa Educational Publishers, Ado-Ekiti. Pp 230-234.

Agbogidi, O.M. and Ofuoku, A.U. (2006). Biodiversity conservation and poverty alleviation in the Niger Delta area of Nigeria. Agriculturea Conspectus Scientifiucs 71(3): 103-110.

Agbogidi, O.M. and Ofuoku, A.U. (2007). Promoting environmental protection in Nigeria through environmental education: the role of woman. Journal of Environmental Extension 6:28-33.

Agbogidi, O. M. and Eshegbeyi, O. F. (2008). Forestry development for a safe environment. In: Onykwelu, J.C., Adekunle, V.A.J. and Oke, D. O. (eds.). Proceedings of the $1^{\text {st }}$ National Conference of the Forests and Forest Products Society of Nigeria (FFPN) held at the Federal University of Technology, Akure, Ondo State between $16^{\text {th }}-18^{\text {th }}$ April, 2008. Pp 95-98.

Agbogidi, O. M. and Okonta, B.C. (2009). Conservation of biodiversity: the goal of sustainable development. African Journal of Agricultural Research and Development. (In press).

Aimufia, D. I. (2002). Forests, people and the environment: a keynote address. In: Popoola, (ed.). Proceedings of a National Workshop organized by FANCONSULT and Edo State Chapter of FAN held in Benin City, Edo State between $5^{\text {th }}$ and $6^{\text {th }}$ of September, 2002. Pp 514.

Aju, P.C. (2002). The potential role of urban forestry in environmental management in Nigeria. In: Abu, J.E., Oni, P. and Popoola, L. (eds.). Proceedings of the $28^{\text {th }}$ annual conference of FAN held in Akure, Ondo State between $4^{\text {th }}$ and $8^{\text {th }}$ and of Nov., 2002. Pp 89-93.

Aliyu, B. S. (2006). Some ethno-medicinal plants of the savannah region of West Africa: description and photochemicals Triumph Publishing Company Ltd, Kano.

Anamayi, S.E., Anamayi, R.M., Bamikole, J.A. and Thomas, T. (2005). Contribution of locust bean fruit to household food security and poverty alleviation among rural dwellers of Igabi Local Government Area of Kaduna State. In: Popoola, L., Mfon, P. and Oni. P.I. (eds.). Proceedings of the $30^{\text {th }}$ Annual Conference of FAN held in Kaduna, Kaduna State, Nigeria. Between $7^{\text {th }}$ and $11^{\text {th }}$ November, 2005. Pp 325-334.

Asaba Metrological Station (2006). .National meteorological report. In: Meteorological Bulletin (2006) Lagos, Nigeria.

Burkill, H. M. (1999). The useful plants of West Africa. Vol. Calesal Piniaceae Royal Botanic Gardens. Longman Publishing U.K.

Etukudo, I. (2000). Forests: our divine treasure. Dorand Publishers, Uyo.

Foskett, N. and Foskett, R. (2004). Conservation. Cox and Wyman Ltd, Reading.

Idumah, F.O., Onyeanusi, A.E. and Ajayi, C.A. (2008). Non -timber forest resource and sustainable livelihood in a rural economy. In: Onykwelu, J.C., Adekunle, V.A.J. and Oke, D. O. (eds.). Proceedings of the $1^{\text {st }}$ National Conference of the Forests and Forest Products Society of Nigeria (FFPN) held at the Federal University of Technology, Akure, Ondo State between $16^{\text {th }}-18^{\text {th }}$ April, 2008. Pp $257-261$.

Iroko, O. A. Kareem, A. A., Adio, A. F. and Gbadebo, J. O. (2008). Impact of human activities on the forest and their effects on climate change. In: Popoola, L. (ed.). Proceedings of the $32^{\text {nd }}$ Annual Conference of FAN held in Umuahia, Abia State, Nigeria between $20^{\text {th }}$ and $24^{\text {th }}$ October, 2008. Pp 208-214. 
Jimoh, S.O. and Haruna, E.A. (2007). Contribution of nontimber forest products to household food security and income around Onigabari forest reserve in Oyo State, Nigeria. Journal of Environmental Extension 6:34-37.

Keay, R.W.J., Onochie, C.F.A. and Stanfield, D.P. (1989). Trees of Nigeria: a revised version of Nigeria trees vols 1 and 2. National Press Ltd, Apapa Lagos. Published by the Department of Forestry Research Institute, Ibadan.

Kuponiyi, F.A. (2007). Socio-economic importance of nontimber forest products among rural residents of Shaki agricultural zone of Oyo State, Nigeria. Journal of Environmental Extension 6: 34-38.

Nwoboshi, L.C. (2000). The nutrient factor in sustainable forestry. University Press, Ibadan.

Oguntade, A.E., and Awolala, D.O. (2010). Poverty and forest conservation in Nigeria; concepts, issues and policy considerations. In: Onyekwelu, J., Adekunle, V.A.J. and Oke, D.O. (eds.). Proceedings of the $2^{\text {nd }}$ biennial National Conference of the Forests and Forest Products Society of Nigeria held at the Federal University of Technology, Akure, Nigeria between $26^{\text {th }}$ and $29^{\text {th }}$ of April, 2010. Pp 67-77.

Okonkwo, M.C., Umar, G. and Nwafor, O.E. (2002). Forest resources depletion and the national economy. In: Abu, J.E., Oni, P.L. and Popoola, L. (eds.). Proceedings of FAN held in Akure, Ondo State, Nigeria between $4^{\text {th }}$ and $8^{\text {th }}$ of November 2002. Pp 94100.

Olajide, O., Apejoye, F. and Chukwuma, B. (2006). A survey of economically valued forest trees and shrubs at the proposed site for airport in Akwa Ibom State, Nigeria. In: Popoola, L. (ed.). Proceedings of the $31^{\text {st }}$ Annual Conference of FAN held in Makurdi, Benue State, Nigeria between $20^{\text {th }}$ and $25^{\text {th }}$ November, 2006. Pp 203-208.

Olajide, O. Udofia, O. and Etigale, E. B. (2008). Consequences of tropical rainforests destruction on the climate and physical environment. In: Popoola, L. (ed.). Proceedings of the $32^{\text {nd }}$ Annual Conference of FAN held in Umuahia, Aba State, Nigeria between $20^{\text {th }}$ and $24^{\text {th }}$ October, 2008. Pp 23-28.

Olufemi, B. and Akinlosutu, M.O. (2006). Contribution of non-wood forest products to the socio-economics of rural dwellers in Idanre, Ondo state, Nigeria. In: Popoola, L, (ed.). Proceedings of the $31^{\text {st }}$ Annual conference of FAN held in Makurdi, Benue state, Nigeria between $20^{\text {th }}$ and $25^{\text {th }}$ Nov. 2006.Pp 516-526.
Omotoyinbo, M. A. and Kayode, J. (2008). Checklist and conservation status of chewing stick plant species in Ekiti State, Nigeria. In: Onykwelu, J.C., Adekunle, V.A.J. and Oke, D. O. (eds.). Proceedings of the $1^{\text {st }}$ National Conference of the Forests and Forest Products Society of Nigeria (FFPN) held at the Federal University of TechnologyAkure, Ondo State between $16^{\text {th }}-18^{\text {th }}$ April, 2008. Pp 109-112.

Oni, Y.M., Onyekwelu, J.and Ajibufun, I.A. (2010).The impact of climate change on forest resources. In. Onyekwelu, J., Adekunle, V.A.J. and Oke, D.O.(eds.). Proceedings of the $2^{\text {nd }}$ biennial National Conference of the Forests and Forest Products Society of Nigeria held at the Federal University of Technology, Akure, Nigeria between $26^{\text {th }}$ and $29^{\text {th }}$ of April,2010. Pp 132135.

Oregbeme, A.O. (2005). Propagation and cultivation of economic non-timber forest product and fruit trees a possibility for poverty alleviation in rural communities in Edo State. In: Orheuata, A.M., Nwokoro, S.O, Ajiayi, M.T., Adekunle, A.T. and Asumugha, G.N. (eds.). Proceedings of the $39^{\text {th }}$ Annual Conference of the Agricultural Society of Nigeria held at the University of Benin, Benin City, Edo State between October 9 and 13, 2005. Pp 242-245.

Popoola, L. (2002). Reducing poverty through non-timber forest products in Nigeria. In: Folusu, O. (ed.). Poverty reduction and the Nigeria agricultural sector. Elshaddai Global Ventures Ibadan. Pp 77-90

Popoola, L. and Oluwalana, S.A. (1998). Marketing of nontimber forest products in Nigeria. In: Adeola, A.O., Okojie, J. and Ojo, L .O. (eds.). Proceedings of colloquium on biodiversity of the rain forest and ecosystem of Nigeria Organized by FEPA-UNAB linkage centre for forest, conservation and biodiversity between $8^{\text {th }}$ and $10^{\text {th }}$ December, 1998. Pp 33-37.

Sale, F. A., Samuel, D. and Ayo-Odifiri, O. S. (2008). Effects of climate change on biodiversity. In: Popoola, L. (ed,). Proceedings of the $32^{\text {nd }}$ Annual Conference of FAN held in Umuahia, Abia State, Nigeria between $20^{\text {th }}$ and $24^{\text {th }}$ October, 2008. Pp 202-207.

Udo, E. S. (2001). The position of forestry in Awa Ibom State. In: Udo, E. S. (ed.). Proceedings of the $1^{\text {st }}$ workshop of the Forestry Association of Nigeria Akwa Ibom State Branch in collaboration with the Department of Forestry and Wildlife, University of Uyo, State Ministry of Environment and the UNDP, Akwa Ibom State held in Uyo, Akwa Ibom State between $10^{\text {th }}$ and $11^{\text {th }}$ April, 2001. Pp 31-43. 